\title{
An investigation of teacher and teacher candidates' views on the course of school experience
}

\author{
Emine Begüm Akkuşs, Lütfi Üredi \\ ${ }^{1}$ Ministry of National Education, Turkey \\ ${ }^{2}$ Department of Primary Education, Mersin University, Turkey
}

\section{Article Info \\ Article history: \\ Received May 23, 2020 \\ Revised Dec 14, 2020 \\ Accepted Jan 21, 2021}

\section{Keywords:}

Candidate teacher

Internship

Practicum

Pre-service teacher training

\begin{abstract}
One of the most important elements involved in the development of countries is teachers. Therefore, developing countries should pay attention to training good teachers. Thus, the purpose of this study was to present the opinions of teachers and prospective teachers on the "teaching experience" course. The study is based on a qualitative research. The data were collected from 84 teachers in Şanliurfa, an eastern city of Turkey and 88 prospective teachers (undergraduate seniors) studying at Mersin University, Turkey. Semistructured interview form was utilized to collect the required data. Besides, content analysis was applied in the study. The data have been expressed in numbers. Results have displayed that there are problems arising from the stakeholders in the "teaching experience" lesson. The types of schools attending internships are not inclusive. Not all stakeholders are working cooperatively. Moreover, the following suggestions were accordingly put forward: 1) The internship duration can be extended; 2) Applications covering all types of schools should be added; and 3) Stakeholders should be encouraged to work in a collaborative way.
\end{abstract}

This is an open access article under the CC BY-SA license.

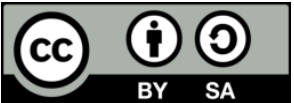

\section{Corresponding Author:}

Emine Begüm Akkuş

Ministry of National Education

Ankara, Turkey

Email: eb.akkus@gmail.com

\section{INTRODUCTION}

Education continued its existence all over the world from past to present. All societies have implicitly or intentionally programmed their education, since each society is in need of qualified manpower. Thus, there is a need for qualified teachers who can educate modern qualified students [1]. There is a high demand for qualified teachers who play an important role in educating students who value science and technology, solve daily problems, and meet the needs of society [2].

Training qualified teachers is important for training qualified students. This improves a country in that the "Teacher training system" (educational experiences and curriculum) and "teaching experience applications" are very important in the formation of teacher identity [3]. Prospective teachers become more experienced through internship. For this reason, societies should put emphasis on "teaching experience practices". Therefore, the teachers of the contemporary world should be well trained to perform the tasks expected from them [4].

Preservice teachers do their internship during their undergraduate education. This is called the "Teaching Experience" course. It is applied in schools affiliated to the Ministry of National Education. Turkey, in the 2018-2019 academic years, began to apply a new undergraduate teaching program last year in which a teaching practice of a total of 24 days, including 12 days for each semester is carried out [5]. The 
practicum gives prospective teachers the opportunity to recognize and apply the profession [6]. The practicum is carried out with the aim of providing teaching skills in the classroom with the management and extracurricular activities in the field where the teacher candidate is educated. It allows the trainee to teach a lesson or lessons in a planned way [7]. It is important to have coordination between the three in order to maintain the practicum effectively; candidate teacher, university supervisor, practicum school supervisor [8].

The related literature represents that the practicum applications utilized in Turkey are not efficient enough as a result of some obstacles. The carried-out studies display that these obstacles are mainly caused by the implementers of the practicum (faculty members, practicum teachers), as well as other reasons such as the insufficiency of the practicum period.

In their studies, Selvi and others [9] indicated that there is a lack of interaction between faculty and practicum school, and the practicum period is not enough to obtain a high-quality practicum experience. They also stated that there has to be a strong interaction between the practicum school, pre-service teachers, and faculty members in order to achieve the specified goals. Eret and Orhan [10] have concluded that the practicum practices of pre-service teachers are not observed and evaluated enough. Süral [11] has found out that practicum teachers are not professionally competent enough to respond to the expectations and needs of the pre-service teachers. Akyıldiz [12] also found out that faculty members do not interact with the practicum teachers since they hesitate getting in touch with the practicum school. Further, Altan, et al. [13] put forward that the practicum period assigned to re-service teachers is limited to attain the needed skills. Tosun [5] also examined the teaching practicum with respect to the time period assigned to it and found out that the time allocated to practicum practices in Turkey is highly limited compared to the practices in Finland and Germany. Özer and Alkan [14] also found out that in such countries as the UK, Portugal, Spain, Italy, and Belgium, the practicum is carried out every school year. Therefore, they suggested that in Turkey, the same practice has to be applied every school year as well as great care must be given when choosing the practicum mentors who have to be educated accordingly.

When examining the literature on teaching practicum, it is clearly understood that the related studies are based on the perspectives of stakeholders. Different from other studies, within this study, both the perceptions of pre-service and in-service teachers on their practicum experiences are inquired. Further, since there seems to be a huge gap in the studies on the practicum and the school types, this study tries to close the mentioned gap accordingly. Thus, this paper aims to explore the types of the practicum school both the preservice and in-service teachers participate in and their related perceptions accordingly. Moreover, it was also aimed to find out the reasons of the problems encountered in the practicum process by means of the views of the informants. In this context, answers to the following questions were sought: What are the views of teachers and prospective teachers on the university advisor of the practicum? What are the views of the teachers and prospective teachers on the school counselor of the practicum? What are the views of teachers and prospective teachers on the internship school? What are the suggestions of teachers and prospective teachers to make practicum more efficient?

After all the specified literature, the study is supposed to stand as a great source to diversify the dimensions of the practicum course, to empower the practicum period, and to force the stakeholders to focus more consciously on the practicum process. Besides, the adaptation problems experienced by the teachers as a result of the differences between the practicum school and the schools they currently work are envisaged within this study.

\section{RESEARCH METHOD}

A qualitative research design was used in the study. Further, survey model was utilized in the study. Survey models are research approaches aiming to describe a situation that exists in the past or still as it exists. The event, individual or object that is the subject of the research is tried to be defined within its own conditions and as it is [15]. The data were collected from 84 teachers in Şanliurfa (Eyyubiye and Harran Districts) and 88 teacher candidates (undergraduate seniors) studying at Mersin University. The demographic data on the study group is given in Table 1 and Table 2.

As can be observed from Table 1, the number of class teachers (19 female \& 7 male) is higher compared to other branches such as Science ( 8 female \& 4 male), Mathematics ( 8 female \& 6 male), Turkish (5 female \& 5 male), Pre-school (10 female \& 2 male), and English ( 9 female \& 1 male). Further, majority of the participants are observed to be between the ages of 21-25 ( $\mathrm{N}=11$ for Class Teacher, $\mathrm{N}=5$ for Science, and $\mathrm{N}=7$ for Mathematics). Lastly, it is clearly understood from Table 1 that majority of the teachers such as Class Teacher $(\mathrm{N}=12)$, Science $(\mathrm{N}=7)$, Mathematics $(\mathrm{N}=7)$, Pre-school $(\mathrm{N}=6)$, and English $(\mathrm{N}=5)$ are between 1-3 years of seniority, while Turkish $(\mathrm{N}=5)$ is between 3-5 years of seniority. 


\begin{tabular}{|c|c|c|c|c|c|c|c|c|c|c|c|}
\hline & \multicolumn{2}{|c|}{ Gender } & \multicolumn{5}{|c|}{ Age } & \multicolumn{4}{|c|}{ Seniority (years) } \\
\hline & Female & Male & $21-25$ & $26-30$ & $31-35$ & $36-40$ & 41 and over & Less than 1 & $1-3$ & $3-5$ & More than 5 \\
\hline Class teacher & 19 & 7 & 11 & 10 & 2 & 2 & 1 & 5 & 12 & 8 & 1 \\
\hline Science & 8 & 4 & 5 & 4 & 2 & 1 & - & 2 & 7 & 3 & - \\
\hline Mathematics & 8 & 6 & 7 & 4 & 1 & 1 & 1 & 3 & 7 & 2 & 2 \\
\hline Turkish & 5 & 5 & 4 & 5 & - & 1 & - & 2 & 2 & 5 & 1 \\
\hline Pre-school & 10 & 2 & 5 & 5 & 1 & 1 & - & 1 & 6 & 4 & 1 \\
\hline English & 9 & 1 & 2 & 4 & 2 & 2 & - & 2 & 5 & 2 & 1 \\
\hline Total & 59 & 25 & 34 & 32 & 8 & 8 & 2 & 15 & 39 & 24 & 6 \\
\hline
\end{tabular}

Table 2 clearly represents the distribution of prospective teachers according to the gender variable. It is simply understood that Class Teacher involves 24 female and 6 male teachers, while the rest of the branches represent diverse dispersion: Science ( $\mathrm{N}=6$ female and $\mathrm{N}=4$ male); Mathematics $(\mathrm{N}=8$ female and $\mathrm{N}=4$ male); Turkish ( $\mathrm{N}=3$ female and $\mathrm{N}=5$ male); Pre-school ( $\mathrm{N}=18$ female and $\mathrm{N}=2$ male); and English $(\mathrm{N}=5$ female and $\mathrm{N}=3$ male) .

Table 2. Distribution of prospective teachers according to gender variable

\begin{tabular}{cccc}
\hline & Female & Male & Total \\
\hline Class teacher & 24 & 6 & 30 \\
Science & 6 & 4 & 10 \\
Mathematics & 8 & 4 & 12 \\
Turkish & 3 & 5 & 8 \\
Pre-school & 18 & 2 & 20 \\
English & 5 & 3 & 8 \\
Total & 64 & 24 & 88 \\
\hline
\end{tabular}

The data of the research were collected through the "Semi-Structured Interview Form". Researchers developed the data collection tool. The questions were prepared as: first, the purpose of the research was determined. The literature was searched appropriately. Inspections were made. Expert opinion was used. As a result of this screening, questions suitable for the purpose of the researcher were created. For the reliability of the data collection tool, pre-application was made with 18 teachers working in different schools and 18 teacher candidates studying in different undergraduate departments. The teachers and prospective teachers who participated in the pre-application were not included in the research later. Validity and reliability analysis were performed on the data obtained in the preliminary study. The following formula was used to test the reliability of the coding made by the researchers [16, 17]. Harmony between Observers $=$ Consensus $/($ Consensus + Disagreement $) \times 100$. In the calculation made according to this formula, the following results were found. Inter-observer compliance ranged from $81.8 \%$ to $92.7 \%$ in each category. It is successful because the interobserver reliability is higher than $80 \%$ [16].

Content analysis was applied to the qualitative data obtained. Thus, the views of the participants were systematically defined [17]. Abbreviations such as $\mathrm{O} 1, \mathrm{O} 2$, and $\mathrm{O} 3 \ldots$ are used for sample teacher opinions, OA1, OA2, and OA3 ... for teacher candidate opinions.

\section{RESULTS AND DISCUSSION}

This section respectively clarifies teachers' opinions about university advisors, teachers' candidates opinions about university advisor, teachers' views on internship school advisors, teachers' candidates opinions about internship school advisor, teachers' views on internship school types, teachers' candidates view on internship school types, teachers' opinions about internship to be more efficient teachers' candidates, and teacher candidates' opinions about internship to be more efficient. Related opinions, frequencies, and remarks of the respondents are illustrated accordingly. Lastly, each dimension is tabulated based on the responses given by the participants. Table 3 represents the teachers' opinions about university advisors. The related aspect is illustrated under subsections as category, opinions, and frequencies. Remarks of the respondents are given in Table 3 . 
Table 3. Teachers' opinions about university advisors

\begin{tabular}{llc}
\hline \multicolumn{1}{c}{ Category } & \multicolumn{1}{c}{ Opinions } & F \\
\hline & About classroom management & 13 \\
& About the course & 13 \\
Positive opinions & About communication with students & 10 \\
(supported) (N:52) & About course preparation & 5 \\
& About material preparation & 4 \\
& About trust and encouragement & 4 \\
& About file and report preparation & 4 \\
& Communication with the teacher candidate & 11 \\
& Communication with the internship & 9 \\
Negative opinions & About feedback and correction & 8 \\
(not supported) (N:42) & About the functioning of the internship & 7 \\
& About classroom management & 5 \\
& Follow the application process & 2 \\
\hline
\end{tabular}

Table 3 clearly represents that the dispersion of the positive opinions is slightly higher than the negative dispersion. Positive opinions $(\mathrm{N}=52)$ respectively refer to such themes as About classroom management $(\mathrm{N}=13)$; About the course $(\mathrm{N}=13)$; About communication with students $(\mathrm{N}=10)$; About course preparation $(\mathrm{N}=5)$; About material preparation $(\mathrm{N}=4)$; About trust and encouragement $(\mathrm{N}=4)$; and About file and report preparation $(\mathrm{N}=4)$. On the other hand, negative opinions $(\mathrm{N}=42)$ respectively refer to such themes as Communication with the teacher candidate $(\mathrm{N}=11)$; Communication with the internship $(\mathrm{N}=9)$; About feedback and correction $(\mathrm{N}=8)$; About the functioning of the internship $(\mathrm{N}=7)$; About classroom management $(\mathrm{N}=5)$; and Follow the application process $(\mathrm{N}=2)$. Related remarks of the respondents are given:

"The advisor helped me with the problems I encountered. I got suggestions especially about effective classroom management and I saw its benefit." (O29)

"At the beginning of the application, my advisor gave the internship school and the report information we will write. Then there was no support." (O44)

"We went to the school where we will be an intern. He shared the necessary information in this regard with us. He supervised us during the application process. He gave information about classroom management and communication." (O59)

Table 4 illustrates the teacher candidates' opinions about university advisors. The related aspect is displayed under subsections as category, opinions, and frequencies. Remarks of the participants are presented in Table 4.

Table 4. Teacher candidates' opinions about university advisors

\begin{tabular}{clc}
\hline Category & \multicolumn{1}{c}{ Opinions } & $\mathrm{F}$ \\
\hline Positive opinions (N:67) & Enough support & 67 \\
& Communication with the internship school & 8 \\
& Information about the internship process & 7 \\
& Uninterested in problems & 5 \\
& Visit the Internship School & 5 \\
Negative opinions (N:33) & Follow the internship process & 4 \\
& Feedback and correction & 3 \\
& Attitude towards teacher candidate & 3 \\
& Objective evaluation & 2 \\
& Not enough equipment & 2 \\
\hline
\end{tabular}

Table 4 shows that the dispersion of the positive opinions is significantly higher than the negative dispersion. Positive opinions $(\mathrm{N}=67)$ refer solely to Enough support $(\mathrm{N}=67)$. However, negative opinions $(\mathrm{N}=33)$ respectively refer to such themes as Communication with the internship school $(\mathrm{N}=8)$; Information about the internship process $(\mathrm{N}=7)$; Uninterested in problems $(\mathrm{N}=5)$; Visit the Internship School $(\mathrm{N}=5)$; Follow the internship process $(\mathrm{N}=4)$; Feedback and correction $(\mathrm{N}=3)$; Attitude towards teacher candidate $(\mathrm{N}=3)$; Objective evaluation $(\mathrm{N}=2)$; and Not enough equipment $(\mathrm{N}=2)$. Related remarks of the informants are stated:

"My advisor provides the necessary support in applications. It makes the necessary information. When it comes to the place, it checks. I have no problem." (OA48)

"There is no problem with my advisor. As it is supposed to be." (OA17) 
"My advisor did not visit the school where I did my internship. I do not think that he is in communication with the internship officers. We go and come to ourselves." (OA32)

Table 5 shows the teachers' views on the internship school advisors. The related dimension is represented under subsections as category, opinions, and frequencies. Remarks of the informants are exemplified in Table 5.

Table 5. Teachers' views on the internship school advisors

\begin{tabular}{clc}
\hline \multicolumn{1}{c}{ Category } & \multicolumn{1}{c}{ Opinions } & F \\
\hline Positive opinions (N:45) & It was helpful enough & 45 \\
& He would have left the classroom & 15 \\
& It was indifferent to our problems & 10 \\
& Inadequate in removing our deficiencies & 9 \\
& Didn't offer enough practical possibilities & 9 \\
Negative opinions (N:49) & Didn't inform about content teaching & 7 \\
& He saw us as a problem & 7 \\
& He couldn't convey his experiences & 6 \\
& Didn't help with classroom management & 5 \\
& Didn't help with student communication & 3 \\
\hline
\end{tabular}

Table 5 displays that the dispersion of the positive opinions is slightly lower than the negative dispersion. Positive opinions ( $\mathrm{N}=45)$ solely put forward It was helpful enough $(\mathrm{N}=45)$, while negative opinions $(\mathrm{N}=49)$ respectively refer to such themes as He would have left the classroom $(\mathrm{N}=15)$; It was indifferent to our problems $(\mathrm{N}=10)$; Inadequate in removing our deficiencies $(\mathrm{N}=9)$; Didn't offer enough practical possibilities $(\mathrm{N}=9)$; Didn't inform about content teaching $(\mathrm{N}=7)$; He saw us as a problem $(\mathrm{N}=7) ;$ He couldn't convey his experiences $(\mathrm{N}=6)$; Didn't help with classroom management $(\mathrm{N}=5)$; and Didn't help with student communication $(\mathrm{N}=3)$. Remarks of the participants are displayed:

"The internship school advisor used the internship days to do their own private work. Most of the time I will deposit, leave somewhere and leave the class to me, saying "I will come and go." (O5)

"The internship school advisor was not interested in me. He did not give enough information about the applications. It didn't help. When I needed, I was consulting him, but he was passing over." (O84)

"I could not find an opportunity to apply. The internship school advisor was more active on his own. I often had to observe." (O73)

Table 6 shows the teacher candidates' opinions about internship school advisors. The related dimension is presented under subsections as category, opinions, and frequencies. Remarks of the respondents are given in Table 6.

Table 6. Teacher candidates' opinions about internship school advisors

\begin{tabular}{llc}
\hline \multicolumn{1}{c}{ Category } & \multicolumn{1}{c}{ Opinions } & $\mathrm{F}$ \\
\hline Positive opinions (N:52) & It helps enough & 52 \\
& He leaves the class to me all day & 25 \\
& He's got me done his own business & 17 \\
& Uninterested in our problems & 13 \\
& Not enough equipment & 12 \\
Negative opinions (N:48) & It lowers my motivation & 8 \\
& It prevents what I want to do & 8 \\
& Does not communicate with me & 5 \\
& She sees me as a babysitter & 5 \\
\hline
\end{tabular}

Table 6 displays that the dispersion of the positive opinions is slightly higher than the negative dispersion. Positive opinions ( $\mathrm{N}=52)$ solely suggest, it helps enough $(\mathrm{N}=52)$, while negative opinions $(\mathrm{N}=48)$ respectively refer to such themes as He leaves the class to me all day $(\mathrm{N}=25)$; He's got me done his own business $(\mathrm{N}=17)$; Uninterested in our problems $(\mathrm{N}=13)$; Not enough equipment $(\mathrm{N}=12)$; It lowers my motivation $(\mathrm{N}=8)$; It prevents what I want to do $(\mathrm{N}=8)$; Does not communicate with me $(\mathrm{N}=5)$; and She sees me as a babysitter $(\mathrm{N}=5)$. Remarks of the participants are displayed: 
"The internship school advisor provides convenience in everything. It makes suggestions and corrections. It gives comfort. We have not had any problems so far." (OA48)

"The internship school advisor determines when I will practice in the classroom. He's being arbitrary. I'm divorced. The internship school advisor does not answer my questions. He is not interested with me. "Never mind," he says. I am uncomfortable with this situation." (OA2)

"The internship school advisor has a holiday during the internship. He's handing over the classroom to me. Every once in a while. Other than that, it does not cause general problems." (OA25)

"Our dialogue with the internship school advisor is very good. But in general, he also gets his work done like report and homework control." (OA71)

Table 7 illuminates the teachers' views on the internship school types. The related dimension is showed under subsections as category, opinions, and frequencies. Some remarks of the participants are involved in Table 7.

Table 7. Teachers' views on the internship school types

\begin{tabular}{clc}
\hline Category & \multicolumn{1}{c}{ Opinions } & F \\
\hline Positive opinions (N:15) & I had the opportunity to apply in all school types & 15 \\
& I did not practice at boarding school & 49 \\
& I did not practice at the village school & 41 \\
& I did not practice at the transport center school & 22 \\
Negative opinions (N:79) & I did not practice in the merged class & 21 \\
& I did not practice in vocational and technical school & 15 \\
& I did not practice in schools with different conditions & 7 \\
& I practiced in a single school & 3 \\
\hline
\end{tabular}

Table 7 displays that the dispersion of the positive opinions is highly lower than the negative dispersion. Positive opinions $(\mathrm{N}=15)$ solely indicates $I$ had the opportunity to apply in all school types $(\mathrm{N}=15)$, while negative opinions $(\mathrm{N}=79)$ respectively refer to such themes as I did not practice at boarding school $(\mathrm{N}=49)$; I did not practice at the village school $(\mathrm{N}=41)$; I did not practice at the transport center school $(\mathrm{N}=22)$; I did not practice in the merged class $(\mathrm{N}=21)$; I did not practice in vocational and technical school $(\mathrm{N}=15)$; I did not practice in schools with different conditions $(\mathrm{N}=7)$; I practiced in a single school $(\mathrm{N}=3)$. Remarks of the respondents are shown:

"I had never done an internship at the boarding school. Now I am working in the study classes. Of course, I did not do an internship for this task. But I am not fully satisfied." (O55)

"I did not do an internship at the transport center schools. Now I am working in a transport center school. While I am on duty, I am also interested in school services. I wish we had an internship related to these tasks." (O37)

"The first school I was appointed to is a village school. I'm still working here. But my internship was not at the village school. I had no chance to observe the village schools. In this respect, I find my internship incomplete." (O60)

"The schools we practiced were always the schools in the city center. Facilities and facilities were good. Their parents were interested in the school. They were schools that function regularly. The place where I started my job is a village school with a combined class. A building in the style of a 1982 hut. I was prepared for this situation. But there should be a little internship time in village schools. " (O14)

Table 8 shows the teacher candidates' views on internship school types. The related dimension is illustrated under subsections as category, opinions, and frequencies. Some remarks of the informants are represented in Table 8 . 
Table 8. Teacher candidates' views on internship school types

\begin{tabular}{clc}
\hline Category & \multicolumn{1}{c}{ Opinions } & $\mathrm{F}$ \\
\hline Positive opinions (N:17) & We practice in all types of schools & 17 \\
& We do not practice in village schools & 28 \\
& We do not practice in any schools outside the city center & 25 \\
& We do not practice in boarding schools & 23 \\
& We do not practice in primary schools with combined classrooms & 15 \\
Negative opinions (N:83) & We do not practice in schools other than well-equipped schools & 12 \\
& We do not practice in transport-based schools & 8 \\
& We do not practice in vocational and technical schools & 6 \\
& We always practice at the same school & 6 \\
& We only practice in public schools & 4 \\
& We only practice in daytime schools & 2 \\
\hline
\end{tabular}

Table 8 represents that the dispersion of the positive opinions is extremely lower than the negative dispersion. Positive opinions $(\mathrm{N}=17)$ only indicates We practice in all types of schools $(\mathrm{N}=17)$, while negative opinions $(\mathrm{N}=83)$ respectively refer to such themes as We do not practice in village schools $(\mathrm{N}=28)$; We do not practice in any schools outside the city center $(\mathrm{N}=25)$; We do not practice in boarding schools $(\mathrm{N}=23)$; We do not practice in primary schools with combined classrooms $(\mathrm{N}=15)$; We do not practice in schools other than well-equipped schools $(\mathrm{N}=12)$; We do not practice in transport-based schools $(\mathrm{N}=8) ;$ We do not practice in vocational and technical schools $(\mathrm{N}=6)$; We always practice at the same school $(\mathrm{N}=6)$; We only practice in public schools $(\mathrm{N}=4)$; and We only practice in daytime schools $(\mathrm{N}=2)$. Remarks of the participants are presented:

"The internship is always at the same kind of schools in the center. After being appointed, we can also work in different school types. We had a chance to see these schools as well." (OA12)

"As a class teacher, I have not seen a combined classroom school. And we don't practice. Unfortunately, the information we receive is only theoretical." (OA51)

"The internship does not prepare us for real duty. Village school, boarding school, etc. We do not see. Internships are carried out only in the central schools with good facilities." (OA77)

Table 9 displays the teachers' opinions about how to make internship more efficient. The related dimension is illustrated under subsections as opinions and frequencies. Some remarks of the respondents are represented in Table 9.

Table 9. Teachers' opinions about how to make internship more efficient

\begin{tabular}{lc}
\hline \multicolumn{1}{c}{ Opinions } & $\mathrm{F}$ \\
\hline Teaching internship should be increased & 31 \\
An internship should be planned for the regions to be used as teachers & 20 \\
An inclusive internship should be planned for all school types & 19 \\
Extra-curricular activities should be included in the internship & 15 \\
Internship should be planned considering different student profiles & 11 \\
The teacher candidate should be respected & 8 \\
The parties in the internship should work in coordination & 7 \\
Internship should cover all levels related to the teacher candidate's own field & 7 \\
Audits should be more serious & 6 \\
More realistic classroom environments should be created & 5 \\
Student size should be considered & 5 \\
The teacher candidate should improve himself & 3 \\
Internship opportunities should be given in schools with different opportunities & 2 \\
Financial support should be given to prospective teachers & 2 \\
\hline
\end{tabular}

Table 9 displays various opinions as to the teachers' opinions about how to make internship more efficient. The pursuing suggestions are the mostly occurred suggestions respectively: Teaching internship should be increased $(\mathrm{N}=31)$; An internship should be planned for the regions to be used as teachers $(\mathrm{N}=20)$; An inclusive internship should be planned for all school types $(\mathrm{N}=19)$; Extra-curricular activities should be included in the internship $(\mathrm{N}=15)$; and Internship should be planned considering different student profiles $(\mathrm{N}=11)$. Some remarks of the participants are stated: 
"The longer internship period is efficient. Also, internships should be done in various school types. By practicing, we can be more ready for the matter." (O33)

"We must find more opportunities to apply the theoretical knowledge we have gained at the university. Teachers should provide convenience to students in this regard. We cannot fix everything by writing a report. There should be more internship opportunities." (O49)

"Will there be any place where we will begin the task of the Republic of Turkey. Therefore, internship should cover our various regions, cultures and climates. There should be an opportunity to observe various student-parent-school profile." (O61)

Table 10 illuminates the teacher candidates' opinions about how to make internship more efficient. The related dimension is illustrated under subsections as opinions and frequencies. Some remarks of the respondents are represented in Table 10.

Table 10. Teacher candidates' opinions about how to make internship more efficient

\begin{tabular}{lc}
\hline \multicolumn{1}{c}{ Opinions } & $\mathrm{F}$ \\
\hline Internship duration should be extended & 28 \\
Internship should start from previous years & 17 \\
Internship should be done in different school types & 15 \\
Internship stakeholders should be more cooperative & 11 \\
Internship should not be during the exam preparation year & 9 \\
Internship counselors should be more willing and equipped & 9 \\
The teacher candidate should be made to feel like a teacher at the internship school. & 8 \\
Prospective teachers should be more active and willing & 6 \\
An internship covering all grades should be done & 5 \\
Advisors should be more interested in the internship process and prospective teachers & 5 \\
Internship school advisors should not leave the course & 4 \\
Teacher candidates should be paid & 3 \\
\hline
\end{tabular}

Table 10 illuminates various points of views as to the teacher candidates' opinions about how to make internship more efficient. The pursuing suggestions are the mostly occurred views respectively: Internship duration should be extended $(\mathrm{N}=28)$; Internship should start from previous years $(\mathrm{N}=17)$; Internship should be done in different school types $(\mathrm{N}=15)$; Internship stakeholders should be more cooperative $(\mathrm{N}=11)$; Internship should not be during the exam preparation year $(\mathrm{N}=9)$; Internship counselors should be more willing and equipped $(\mathrm{N}=9)$; and The teacher candidate should be made to feel like a teacher at the internship school $(\mathrm{N}=8)$. Remarks of the respondents are:

"More practice should be done. Theoretical knowledge remains limited. We need to spend a longer time in the school environment. The scope of the internship should be increased. We'd better see all the conditions and environments." (OA21)

"The first year of the license passes with harmonization and theoretical knowledge. But the internship should definitely start from the 2nd year." (OA59)

"There should be no internship. Going to the same school in a limited timeframe does not give us credit. Practice should be more. This is required for adaptation." (OA73)

"The internship school counselor has no contact with the university counselor. It shouldn't be that way. Everyone should be in cooperation. It should not put the teacher candidate in trouble." (OA86)

The findings of the study suggest that 52 teachers are positive towards the faculty member responsible for the practicum, while 42 teachers are negative towards the interaction between candidate teachers and the practicum school. Further, 67 candidate teachers were positive towards the related interaction while 33 candidate teachers were negative towards the interaction and being informed about the practicum process. Mete, et al. [18]; Çepni, et al. [19] also concluded that university supervisors supplied enough support to candidate teachers. The common negative opinions of teachers and candidate teachers involve the disconnection between the university supervisors with the practicum school. Further, Batmaz and Ergen [20] suggested that the university supervisors should visit practicum schools more frequently and follow the process closely.

With respect to the school supervisors responsible for the candidate teachers, 45 teachers uttered positive views, while 49 teachers represented negative attitudes, and 52 candidate teachers put forward positive views, while 48 candidate teachers stated negative opinions towards the related dimension. Both teachers and prospective teachers reported that the internship school counselor left the class during the

An investigation of teacher and teacher candidates' views on the course of school ... (Emine Begüm Akkuş) 
internship process. The result of the research done by Paker [21] supports this result accordingly. The preservice teachers emphasized that they were indifferent to their problems. The result of the research conducted by Baştürk [22] supports this result as well. Özdaş [23] determined in his research that the practicum supervisor did not display enough care towards the candidate teacher. Moreover, Batmaz and Ergen [20] found out in their research that the practicum supervisor left the class during the practice, and accordingly the candidate teacher could not get enough guidance during the process.

With respect to the type of practicum school, 15 teachers declared positive views, while 79 teachers represented negative attitudes, and 17 candidate teachers were positive towards the related issue, while 83 candidate teachers were negative towards it. More than three-quarters of teachers and candidate teachers reported negative opinions towards the types of schools in which they had the practicum. Both groups stated that there are no practicum opportunities in rural schools and boarding schools as well. In their research, Y1lmaz and Namli [24] stated that practicum schools which provide more benefit for candidate teachers should be preferred for the practicum.

According to the findings of the study, there is a communication problem between the university advisor and the internship school advisor. Based on the findings of the study, they did not manage the process well. The results of the research conducted by Şahin \& Özkılıç [25]; Aslan \& Sağlam [26]; Gökçe \& Demirhan [27] supported this result successively. In their research, Kırksekiz, et al. [1] reported that the lack of cooperation and communication between the practicum supervisor and the university supervisor affected the process negatively. Likewise, in their study, Selvi, et al. [9], as well as Özdaş and Çakmak [28] reported that the cooperation between faculty and practicum school, and university supervisor and practicum supervisor could not be achieved adequately. Bay, Şeker and Alisinanoğlu [29] also emphasized the lack of collaboration between candidate teachers and their supervisors in their study. Both teachers and prospective teachers have a common view on extending the internship period in order to make the internship more affective. They suppose that the internship should cover all types of schools. The results of the research conducted by Aslan \& Sağlam [26]; Kavas \& Bugay [30]; Gömleksiz, et al. [31]; Şahin [32]; Çakmak [33]; Ulum [34, 35]; Karasu-Avc1 \& İbret [36] support the present study.

\section{CONCLUSION}

The practicum process, which requires coordination, cooperation and coordination, has many dimensions. In this study, teachers and candidate teachers received adequate support from university supervisors. In addition, it has been determined that there are cooperation and communication problems with university supervisors and practicum stakeholders. Another conclusion reached is that the practicum supervisors leave the class during lessons and do not communicate with candidate teachers. Coordination between the stakeholders on the other hand found out to be required. Based on the views of practicum teachers and candidate teachers, practicum is not carried out in most school types. Both groups agree that there is no practicum in rural schools and boarding schools. Since teaching is a profession performed in every situation and condition after starting the job, teachers need to be prepared for difficult conditions during their undergraduate education, so the number of the types of schools where the practicum is done should be more.

In this study, the problems stated by the candidate teachers should also be seen as suggestions. The candidate teachers put forward that the short practicum period is a problem since the given time is not enough for the required school experience. It can be said that the practicum is limited to once a week and it is insufficient in terms of candidate teachers' adaptation to the profession. Looking at the views of teachers and candidate teachers, the following suggestions can be made to make the practicum more effective: 1) Internship duration should be extended. Teachers should be given the chance to practice more; 2) Coordination of the parties participating in the internship process should be ensured. Stakeholders must fulfill their responsibilities. Cooperation between the faculty and the school should be more effective; 3) The internship should take into account the situations that a teacher may encounter after starting his career; 4) The potential of the type of school in which prospective teachers can take part should be taken into account. Planning should be done accordingly. Better guidance should be provided.

\section{REFERENCES}

[1] A. Kırksekiz, M. Uysal, O. İşbulan, Ö.E. Akgün, M. Kıyıcı and M.B. Horzum, "Okul deneyimi ve öğretmenlik uygulaması derslerine eleştirel bir bakış: problemler, beklentiler, çözüm önerileri,” Bartın Üniversitesi Eğitim Fakültesi Dergisi, vol. 4, no. 2, pp. 433-451, 2015.

[2] H.Ş. Ayvacı, D. Özbek and S. Bülbül, "Bir öğretmenlik uygulaması sürecinin farklı katılımcılar tarafindan değerlendirilmesi," Bolu Abant İzzet Baysal Üniversitesi Eğitim Fakültesi Dergisi, vol. 19, no. 1, pp. 57-66, 2019. 
[3] I. Ünal, “Öğretmenliğe ve öğretmen yetiştirmeye ilişkin ekonomi politik bir çözümleme,” (Ed. Aynal, S.) Türkiye'de Ögrretmen Yetiştirme, pp. 3-23. Pegem Akademi, Ankara, 2011.

[4] A.R. Erdem, Ögrretmen yetiştirmenin bugünü ve geleceği: Sorunlar ve çözüm önerileri. Ankara: Anı Yayınlar1Eğitim Dizisi, 2013.

[5] F. Çam Tosun, "Öğretmenlik uygulamasının süre açısından incelenmesi ve bir çözüm önerisi," Ankara Üniversitesi Eğitim Bilimleri Fakültesi Dergisi, vol. 52, no. 3, pp. 839-869, 2019.

[6] K. Goodnough, T. Falkenberg and R. MacDonald, "Examining The Nature of Theorypractice Relationship in Initial Teacher Education: A Canadian Case Study," Canadian Journal of Education, vol. 39, no. 1, pp. 1-28, 2016.

[7] Milli Eğitim Bakanlığı, "Öğretmenlik uygulaması yönergesi,” Tebliğler Dergisi, vol. 81, no. 2729, pp. 2000-2017, 2018.

[8] S. Şimşek, V. Alkan, and A.R. Erdem, "Öğretmenlik uygulamasına ilişkin nitel bir çalışma," Pamukkale Üniversitesi Ĕgitim Fakültesi Dergisi, no. 34, pp. 63-73, 2013.

[9] M. Selvi, M. Doğru, T. Gencosman and D. Saka, "Fen bilimleri öğretmen adaylarının okul deneyimi ve öğretmenlik uygulaması derslerine ilişkin görüşlerinin etkinlik kuramına göre incelenmesi," Ondokuz Mayıs Üniversitesi Ĕ̈itim Fakültesi Dergisi, vol. 36, no. 1, pp. 175-193, 2017.

[10] E. E. Orhan, "What do teacher candidates in turkey think about their teacher education? A qualitative study," Education and Science, vol. 42, no. 189, pp. 197-216, 2017.

[11] S. Süral, "Sınıf öğretmenliği öğretmen adaylarının öğretmenlik uygulaması dersindeki uygulama öğretmenleri hakkındaki düşüncelerinin incelenmesi," Bilecik Şeyh Edebali Üniversitesi Sosyal Bilimler Enstitüsü Dergisi, vol. 2, no. 1, pp. 277-299, 2017.

[12] S. Akyıldız, "Examining the Levels of Fulfillment of the Duties and Responsibilities of Teacher Training Supervisors and Coordinating Teachers," Asian Journal of Instruction, vol. 6, no. 1, pp. 21-39, 2018

[13] R. Yıldız Altan, İ. Ulutaş and S. Demiriz, "Okul öncesi öğretmenliği lisans programında yer alan "öğretmenlik uygulaması' dersine ilişkin görüşlerin karşılaştırılması,” Gazi Üniversitesi Gazi Eğitim Fakültesi Dergisi, vol. 38, no. 3, pp. 869-886, 2018.

[14] B. Özer and S. Alkan, "AB ve Türkiye öğretmen yetiştirme programlarının karşılaştırılması ve Türkiye için bir model önerisi,” Disiplinlerarası Eğitim Araştırmaları Dergisi, vol. 1, no. 1, pp. 62-95, 2017.

[15] N. Karasar, Scientific research method. Nobel Publishing, Ankara, 2006.

[16] F. Gökçe, "Öğretmen ve velilerin, öğrencilerin okulda geçirdikleri zaman, ders ve dinlenme süreleri ile tatiller ve okul dönemleri konusundaki görüşleri," Kuram ve Uygulamada Eğitim Bilimleri, vol. 12, no. 4, pp. 2541-2560, 2012.

[17] R. Altunışı, R. Coşkun, S. Bayraktaroğlu and E. Yıldırım, Sosyal bilimlerde araştırma yöntemleri spss uygulamall, 6. bask1. Sakarya Yayıncılık, 2010

[18] H. Mete, A. Erdem, G. Uzal, D. Hüyük and S. Altay, "Öğrencilerin öğretim elemanı ve danışman memnuniyeti: Tekirdă̆ NKÜ Teknik Bilimler MYO Örneği,” Kırklareli Üniversitesi Sosyal Bilimler Dergisi, vol. 2, no. 2, pp. 27-42, 2018.

[19] O. Çepni, F. Aydın and V. Şahin, "Coğrafya Öğretmen Adaylarının Öğretmenlik Uygulaması Dersine İlişkin Görüsleri," Cumhuriyet Uluslarararl Eğitim Dergisi, vol. 4, no. 1, pp. 35-49, 2015.

[20] O. Batmaz and Y. Ergen, "İlkokul öğretmenleri ve öğretim üyelerinin öğretmenlik uygulaması dersine yönelik görüşleri,” Ankara Üniversitesi Eğitim Bilimleri Fakültesi Dergisi, pp. 1-27, 2020.

[21] T. Paker, "Öğretmenlik uygulamasında öğretmen adaylarının uygulama öğretmeni ve uygulama öğretim elemanının yönlendirmesiyle ilgili karşılaştıkları sorunlar,” Pamukkale Üniversitesi Eğitim Fakültesi Dergisi, vol. 1, no. 23, pp. 132-139, 2008.

[22] S. Baştürk, "Öğretmenlik uygulaması dersinin öğretmen adaylarının görüşlerine göre incelenmesi,” İlköğretim online, vol. 8, no. 2, pp. 439-456, 2009.

[23] F. Özdaş, "Evaluation of pre-service teachers' perceptions for teaching practice course," Educational Policy Analysis and Strategic Research, vol. 13, no. 2, pp. 87-103, 2018.

[24] A.Y1lmaz and S. Naml, "The opinions of supervising teachers and teacher cadidates participated to teaching practice about professional competency," International Journal of Human Sciences, vol. 14, no. 3, pp. 3061-3077, 2017.

[25] E. Şahin and R. Özkılıç, “Okul Öncesi Eğitimi Öğretmen Adaylarının Uygulama Dersleri Için Hazırlanan Uygulama Kılavuzu Hakkındaki Görüşleri,” Gazi Üniversitesi Gazi Eğitim Fakültesi Dergisi, vol. 25, no. 2, pp. 115-133, 2005.

[26] M. Aslan and M. Sağlam, "Öğretmenlik uygulaması dersinin öğretmen adaylarının görüşlerine göre değerlendirilmesi," Hacettepe Üniversitesi Eğitim Fakültesi Dergisi, vol. 33, no. 1, pp. 144-162, 2018.

[27] E. Gökçe and C. Demirhan, "Öğretmen adaylarının ve ilköğretim okullarında görev yapan uygulama öğretmenlerinin öğretmenlik uygulaması etkinliklerine ilişkin görüşleri," Ankara Üniversitesi Ĕgitim Bilimleri Fakültesi Dergisi, vol. 38, no. 1, pp. 43-71, 2005.

[28] F. Özdaş and M. Çakmak, "Öğretmen adaylarının öğretmenlik uygulaması dersine ilişkin metaforik algıları," Uluslararası Türkçe Edebiyat Kültür Eğitim Dergisi, vol. 7, no. 4, pp. 2747-2766, 2018.

[29] D.N. Bay, P.T. Şeker and F. Alisinanoğlu, "Öğretmenlik uygulaması dersine ilişkin öğretmen adaylarının görüşleri," Anadolu Üniversitesi Ĕ̌itim Fakültesi Dergisi (AUJEF), vol. 4, no. 1, pp. 1-20, 2020.

[30] A.B. Kavas and A. Bugay, "Öğretmen adaylarının hizmet öncesi eğitimlerinde gördükleri eksiklikler ve çözüm önerileri,” Pamukkale Üniversitesi Eğitim Fakültesi Dergisi, vol. 25, no. 25, pp. 13-21, 2009. 
[31] M.N. Gömleksiz, A.U. Kan and Ü. Öner, "Etkili öğretmenlik eğitimi perspektifinde öğretmenlik uygulamas1 dersine eleştirel bir yaklaşım: Nitel bir inceleme," Tarih Okulu Dergisi, vol. 10, no. 32, pp. 927-954, 2017, doi: 10.14225/Joh1131.

[32] M. Şahin, "Pedagojik formasyon eğitimi uygulama dersinin (staj) öğretmen adaylarının görüşleri açısından değerlendirilmesi," Akademik Sosyal Araștırmalar Dergisi, vol. 4, no. 22, pp. 32-49, 2016.

[33] M. Sünkür Çakmak, "Öğretmen adaylarının öğretmenlik uygulaması derslerine ilişkin görüşleri,” Sosyal Bilimler Enstitüsü Dergisi, vol. 13, pp. 207-226, 2019.

[34] Ö. G. Ulum, "Pre-service english teachers' practicum expectations and attainments," Turkish Studies - Education, vol. 15 , no. 2, pp. 1287-1297, 2020.

[35] Ö. G. Ulum, "Pre-service English teachers' narrative identity," Journal of Education Culture and Society, vol. 11, no. 1, pp. 92-101, 2020

[36] E. Karasu-Avcı and B.Ü. İbret, "Öğretmenlik uygulaması-II dersine ilişkin okul öncesi öğretmen adaylarının görüşlerinin değerlendirilmesi,” Kastamonu Eğitim Dergisi, vol. 24, no. 5, pp. 2519-2536, 2016. 